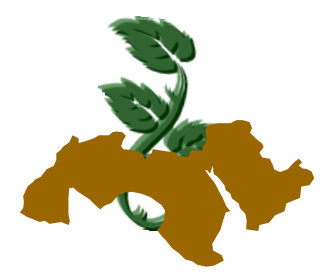

Arab Univ.

J. Agric. Sci., Ain Shams Univ., Cairo, 19(1), 217-231, 2011

\title{
PHYSIOLOGICAL RESPONSE OF STRAWBERRY GROWN IN ROOT- KNOT NEMATODE INFESTED SOIL UNDER DIFFERENT SAFETY CONTROL APPLICATIONS
}

\author{
Mahdy', M.E. and Sally A. Midan² \\ 1- Dept. of Agric. Botany, Fac. of Agric.; Minufiya Univ.; Shebin El-Kom; Egypt \\ E-Mail: mahdymagdy@yahoo.com \\ 2- Dept. of Horticulture, Fac. of Agric.; Minufiya Univ.; Shebin El-Kom; Egypt \\ E-Mail: Sally.midan@yahoo.com
}

Keywords: Strawberry (Fragaria ananassa); Rhizobacteria; Physical Control; Antioxidant; Biological Control; Root-knot nematodes Meloidogyne spp.

\section{ABSTRACT}

Two successive field experiments during two seasons of 2008 and 2009, were carried out to evaluate some safety treatments including: mulching, tunnels, natural yeast extract, antioxidant and two rhizobacteria Serratia marcescens and Pseudomonas fluorescens towards root-knot nematode Meloidogyne spp. on strawberry plant grown in naturally infested soil and consequently their probable effects on growth parameters, chemical components and yield of strawberry compared to untreated control. Results of this study confirmed that all used treatments, significantly reduced all related nematode parameters i.e. number of galls/root system; number of egg masses/root system as well as number of juveniles $/ 250 \mathrm{~g}$ soil łeither after 2 or 4 months when compared to plants grown in the naturally infested soil only. The highest percentage of reduction in all related nematode parameters were noticed after 4 months. Mulching, $S$. marcescens, $P$. fluorescens and tunnels, played an important role in reducing the percentage of nematode parameters. Mulching and $S$. marcescens reduced the percentage of gall numbers/root system by $77 \%$, followed by tunnels by $75 \%$ and $P$. fluorescens by $70 \%$. S. marcescens reduced the percentage of egg masses/root system by $80 \%$ followed by $P$. fluorescens by $78 \%$ and mulching by $76 \%$. Results indicated that the soil treated with mulching, also significantly reduced the percent- age of juvenile numbers $/ 250 \mathrm{~g}$ soil by $79 \%$ followed by $S$. marcescens by $73 \%$. Results confirmed also that all used treatments significantly increased all related plant growth characters viz. leaves, stems, root fresh and dry weight; plant height, leaves number, root length as well as false stem length. Moreover, these treatments significantly increased the activity of some oxidative enzymes e.g. peroxidase and phenoloxidase as well as some other chemical components i.e. total soluble solids (T.S.S \%) and vitamin C (V.C). Results revealed that all previous treatments significantly increased the early and total yield. Our results confirmed that, the rhizobacterium $S$. marcescens came in the first rank as a promoter of all related plant growth characters, followed by tunnels and mulching treatments. Results confirmed that also the antioxidants, are considered the effective one in enhancing the activities of peroxidase and phenoloxidase as well as T.S.S\% and V.C followed by the natural yeast extract.

\section{INTRODUCTION}

Recently, strawberry (Fragaria ananassa) is one of the most important vegetable crops in Egypt for export as well as for its importance in local fresh consumption and food processing.

As any crop grown in a large scale, strawberry is attacked by several pathogenic organisms i.e. fungi, bacteria, virus, plant-parasitic nematodes as well as some insects causing serious losses. Rootknot nematodes Meloidogyne spp. are considered one of the most economically important group of plant-parasitic nematode cause damage and high yield losses on most cultivated vegetables 
throughout the world especially in developing countries (Netscher and Sikora, 1990). Moreover they cause a big problem in strawberry production especially in sandy soil in Egypt.

In the last decades farmers were used fumigation by methyl bromide in strawberry nurseries to control soil insects, fungal diseases, weeds and plant parasitic nematodes as reported by Netscher and Sikora (1990). This method is very expensive, positioning in the cropping system, and lack of the farmer acceptance for its toxicity to humans and the environment.

Although chemical nematicides are effective, easy to apply and show rapid effects, they have begun to be withdrawn from the market in some developed countries owing to concerns about public health and environmental safety (Schneider et al 2003). Nowadays, nematologists all over the world are keeping searching for novel, environmentally friendly alternative control methods to avoid soil and environment pollution with nematicides and subsequently the hazardous effects due to its residues (Tian et al 2007 a\&b). Resistant cultivars, natural organic manure, crop rotation including trap plants and biological control are now the recommended as alternative control methods.

Therefore, the present study was undertaken to evaluate the effect of some safety treatments viz. mulching, tunnels, natural yeast extract, antioxidant, the rhizobacteria $S$. marcescens and $P$. fluorescens on root-knot nematode control on strawberry grown in naturally infested soil and its effect on strawberry growth, yield and chemical components.

\section{MATERIALS AND METHODS}

These experiments were conducted in two successive seasons of 2008 and 2009 at the Experimental Farm of Faculty of Agriculture, Minufiya Univ., Shebin El-Kom to evaluate the effect of mulching, tunnels, natural yeast extract, antioxidant, $S$. marcescens and $P$. fluorescens on the root-knot nematodes, Meloidogyne spp. and the response of strawberry plants cv. Sweet charley grown in nematode naturally infested soil.

The experimental design was a complete randomized block in a three replicates per treatment. The experimental plot area was $30 \mathrm{~m}^{2}$ (6 ridges, with $5 \mathrm{~m}$ long, $1 \mathrm{~m}$ wide) and the distance between the plants was $25 \mathrm{~cm}$.

Seedlings were transplanted in two ridges on 16 and 18 October in 2008 and 2009 seasons, respectively. The recommended doses of $\mathrm{N}, \mathrm{P}$ and
$\mathrm{K}$ chemical fertilizers were: $1000 \mathrm{~kg} / \mathrm{fed}$ ammonium sulphate; $200 \mathrm{~kg} / \mathrm{fed}$ calcium superphosphate and $500 \mathrm{~kg} / \mathrm{fed}$ potassium sulphate.

\section{The experimental treatments were used as fol- lows}

1- Mulching (black color) 2-Tunnels (transparent color) 3-Natural yeast extracts 4- Antioxidants 5- S. marcescens 6- P. fluorescens 7- Control (naturally infested plants with Meloidogyne spp.).

Natural yeast extract and antioxidants were obtained from the Horticulture Research Institute, Dept. of Vegetable Research, Dokki, Giza, Egypt. The chemical analysis of both natural yeast extracts and antioxidants were as follows:

\section{Natural Yeast Extract Contains}

a- Macro-and micro-minerals b- Amino acids
c- Carbohydrate d-Enzymes e- Vitamins.

\section{Antioxidants Contains}

a- Alpha-tocopherol b-Carotenoides c-Ascorbate
d- Citrate e-Zinc f-Selenium

Both of yeast and antioxidant were prepared according to the recommended dose for vegetable crops.

Each plant received $10 \mathrm{ml}$ of yeast extract, antioxidant, $S$. marcescens and $P$. fluorescens as a soil drench and each material was replicated twice at 15 days intervals of planting. The density of both rhizobacteria was determined by serial dilution technique and adjusted to optimum density $\left(O D_{560}=2.0\right)$ by using spectrophotometer representing $2.0 \times 10^{9}$ and $4.0 \times 10^{9} \mathrm{cfu} / \mathrm{ml}$, respectively (Magdy Mahdy, 2002).

\section{Nematode parameters}

Number of juveniles in each soil plot was determined before applying the treatment at zero time. After 2 and 4 months of strawberry seedlings transplanting, number of galls/root system; number of egg masses/root system as well as number of juveniles/250 g soil were recorded. Egg masses were recorded by dipping the roots in $0.015 \%$ Phloxine-B staining-solution for 20 minutes as described by Daykin and Hussey (1985) and then the stained roots were washed with tap water to remove the residual Phloxine $B$. 
Two vegetative plant samples were also undertaken after 2 and 4 months of transplanting, as the following data were recorded:

\section{1- Plant growth parameters}

Plant height $(\mathrm{cm})$, root length $(\mathrm{cm})$, false stem length $(\mathrm{cm})$, leaves number, fresh and dry weights of plant shoot and root (g/plant).

\section{2- Chemical parameters}

Antioxidant enzymes i.e. peroxidase and phenoloxidase activities were measured in the optimum density in fresh weight (O.D/g). Optimum density in fresh weight was determined in fresh leaf samples after 2 and 45 minutes and then was extracted by the method of Fehrman and Dimond (1967) and Broesh (1954), respectively.

\section{3- Yield and its components}

a) The early yield was calculated from the first day of harvesting up to the middle of March.

b) The total yield was calculated from the first day up to last day of harvesting.

c) Total soluble solids were determined by using abbe refractometer as recommended in A.O.A.C. (1990).

d) Vitamin $\mathrm{C}$ was determined $(\mathrm{mg} / 100 \mathrm{~g}$ fresh weight) using the dye 2,6 dichlorophenol indophynol method as mentioned in A.O.A.C. (1990).

Data were statistically analyzed by using Software Statgraphics Version 3.1 for Windows. Duncan's Multiple Range Test was used to test for significant differences among means at $\mathrm{P} \leq 0.05$.

\section{RESULTS}

\section{1- Nematode Parameters}

Results of this study revealed that, all applied treatments reduced all nematode related parameters i.e. number of galls and egg masses/root system as well as number of infective juveniles/250 soil either after 2 or 4 months when compared with untreated plants. Also, results indicated that the highest percentage of reduction of all nematode parameters was noticed after 4 months when compared with 2 months.

Concerning the root galls, results revealed that, mulching treatment was the most effective one in reducing the percentage of galls followed by the rhizobacteria $S$. marcescens and $P$. fluorescens and then tunnels either after 2 or 4 months as shown in Fig. (1). The reduction percentage in galls after 4 months reached $77,77,75$ and $70 \%$, respectively. Treating the soil with yeast extract was the lowest effective one in reducing galls percentage as shown in Fig. (1).

Moreover, the reduction percentage in egg masses/root system was noticed also after 2 and 4 months. However, the highest reduction in egg masses percentage noticed clearly after 4 months compared to 2 months as shown in Fig. (2). Mulching; S. marcescens; $P$. fluorescens and tunnels were the effective treatments in reducing egg masses percentage. The reduction percentages after 4 months were: 80, 78, 76 and $73 \%$, respectively. Yeast extract treatment showed the least effect on egg masses as the reduction percentage reached $54 \%$ as shown in Fig. (2).

The same trend of results was obtained also to infective juveniles in soil as the treatment of mulching and $S$. marcescens approved to be the effective ones in reducing the percentage of infective juveniles in soil either after 2 or 4 months, followed by tunnels and $P$. fluorescens as shown in Fig. (3). The percentage of reduction after 4 months reached $79,73,69$ and $68 \%$, respectively. However, treating the plants with natural yeast extract resulted in low reduction in the percentage of infective juveniles in soil by $28 \%$ as shown in Fig. (3). Moreover, the antioxidant treatment played an important role also in reducing the percentage of all related nematode parameters compared with the check untreated plants, but it came between the $4^{\text {th }}$ and the $5^{\text {th }}$ rank in effectiveness (Fig. 3).

Generally, it can be concluded that all applied treatments had the ability in reducing the nematode activities. In this respect, covering the soil with black color plastic sheets as a mulching treatment came in the $1^{\text {st }}$ rank, followed by both rhizobacteria $S$. marcescens and $P$. fluorescens, then tunnels by transparent color sheets, whereas natural yeast extract treatment came in the last rank.

\section{2- Plant growth parameters}

Plant growth was evaluated as plant height, leaves number, root length, false stem length and leaves, stems, roots fresh and dry weights as shown in Fig. (4 A,B,C,D,E,F,G,H,I and J).

In this study all treatments gave superior records in all studied growth parameters when compared to control. In this connection, mulching, tunnels and $S$. marcescens proved in general to be the best one. Similar trends were, generally, noticed in both seasons. 


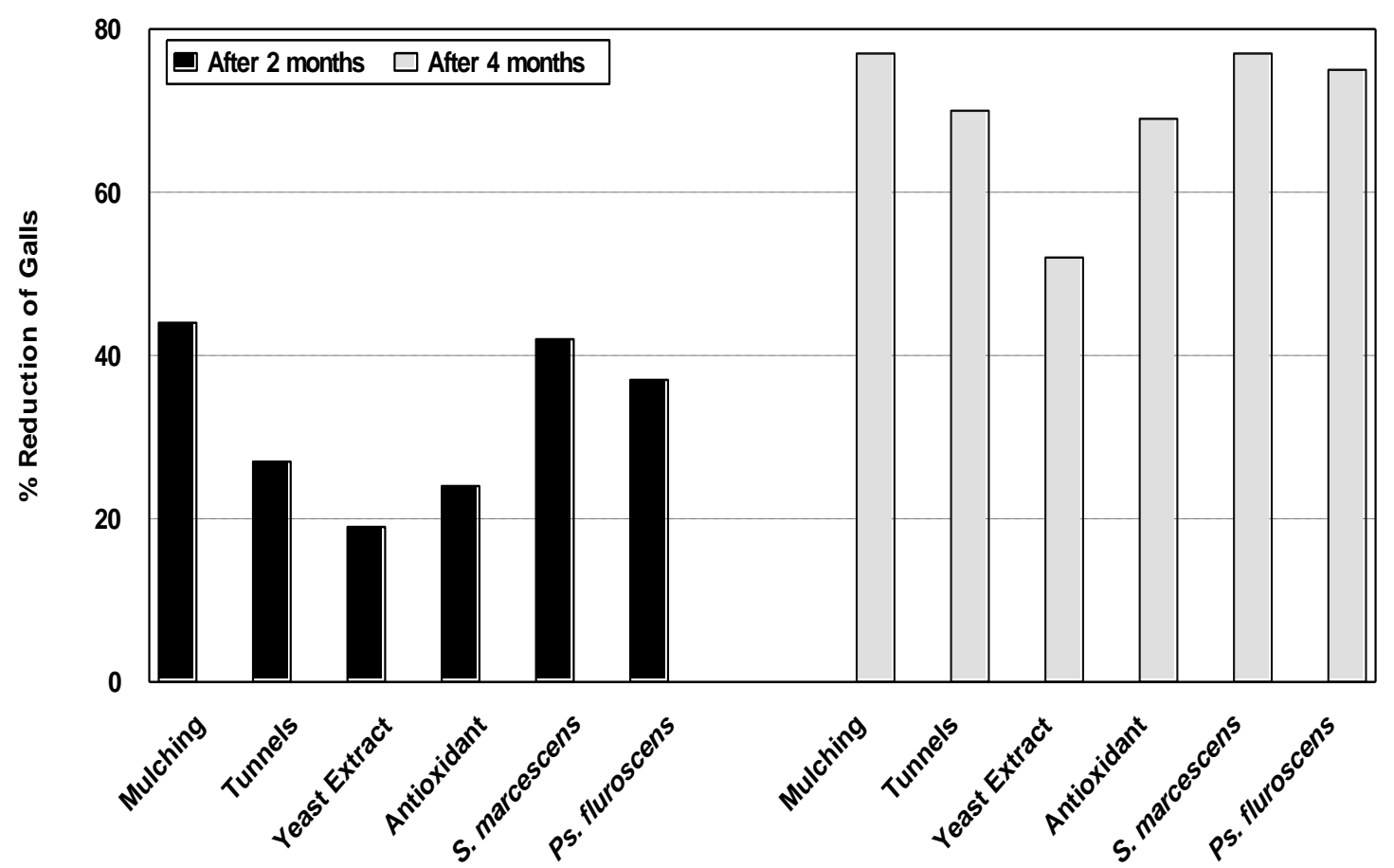

Figure 1. Effect of different treatments on the percentage of gall reduction in strawberry plants grown in naturally infested soil with Meloidogyne spp.

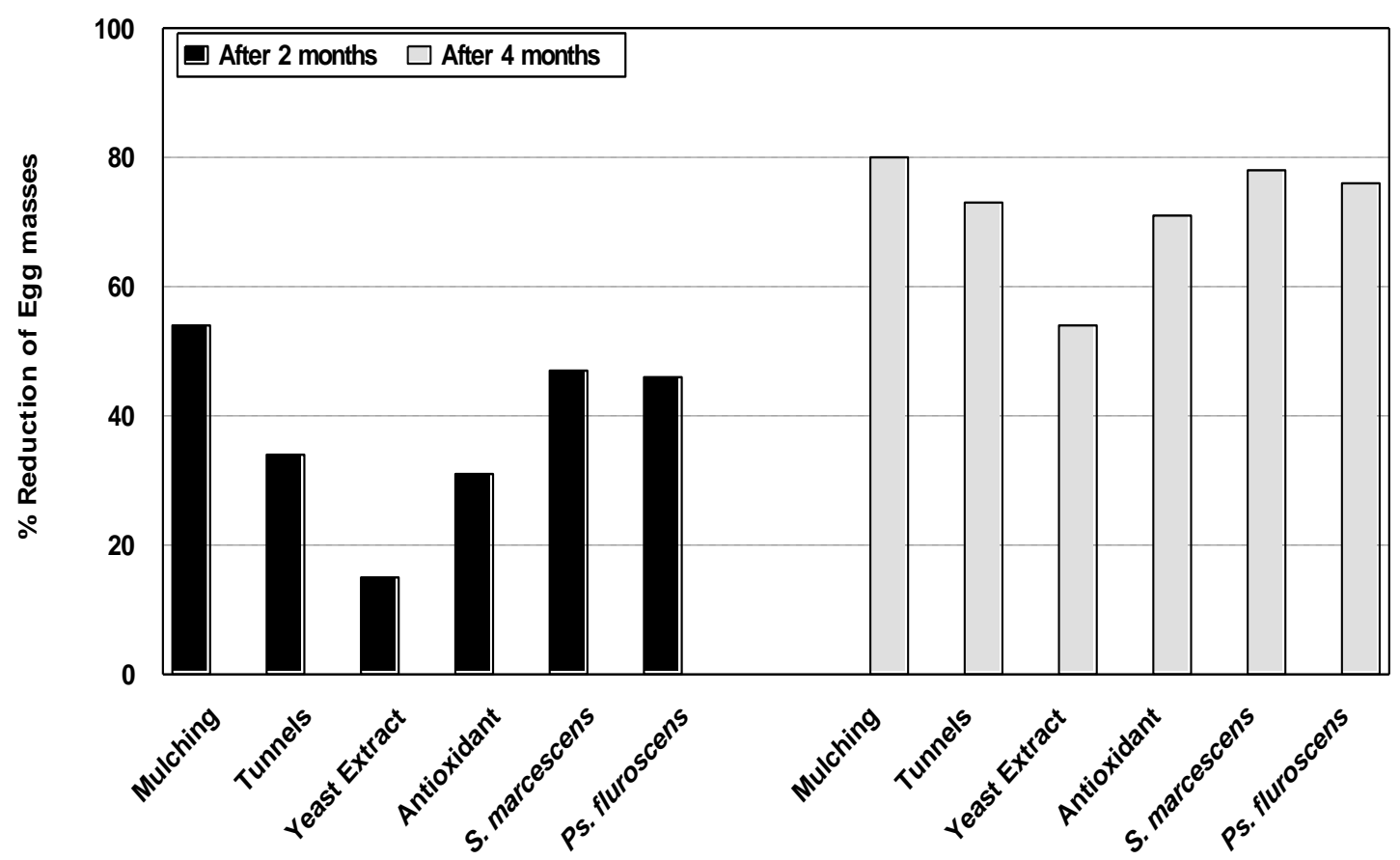

Figure 2. Effect of different treatments on the percentage of egg masses reduction in strawberry plants grown in naturally infested soil with Meloidogyne spp. 


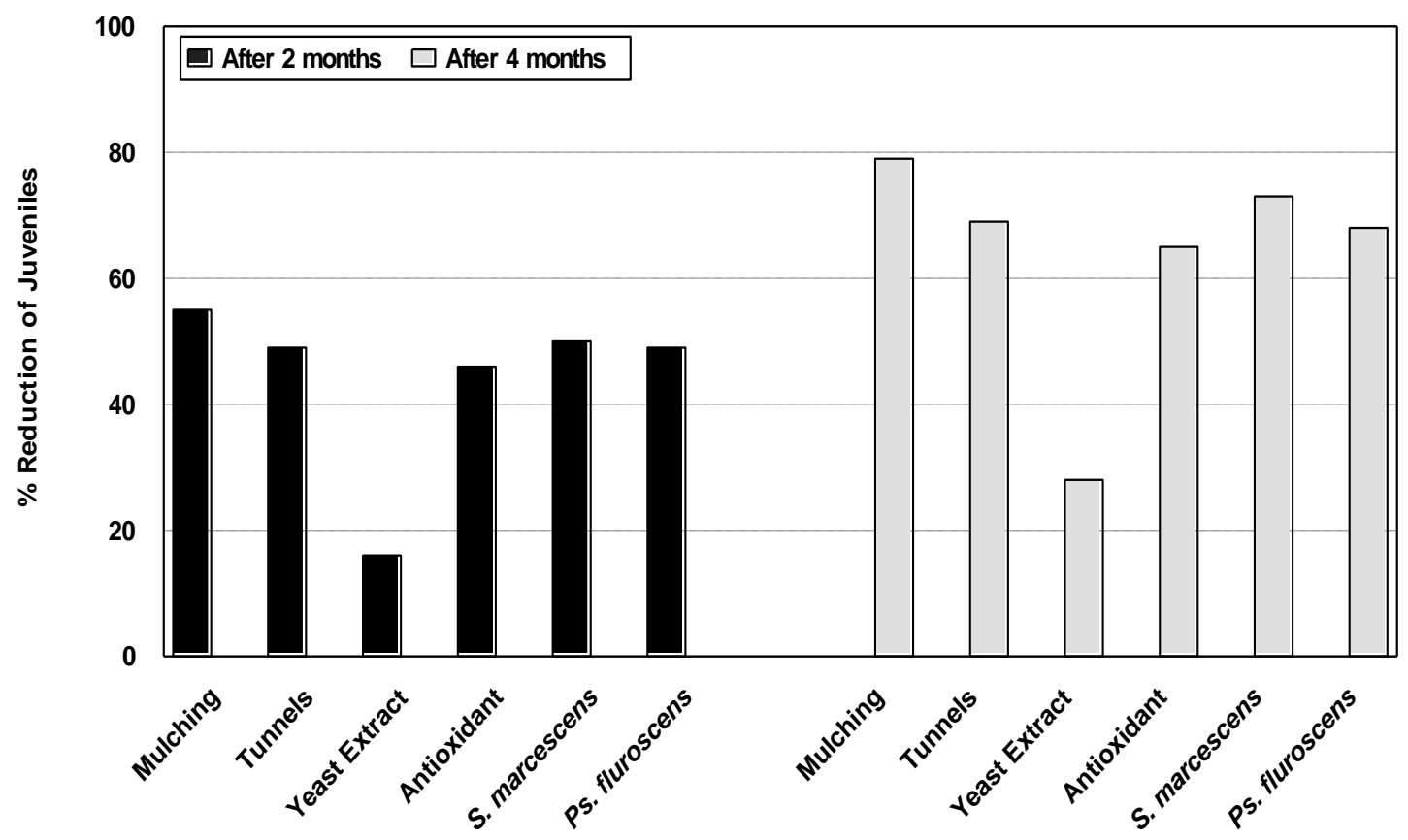

Figure 3. Effect of different treatments on the percentage of reduction of infective juveniles in naturally infested soil with Meloidogyne spp. cultivated with strawberry.

(A)

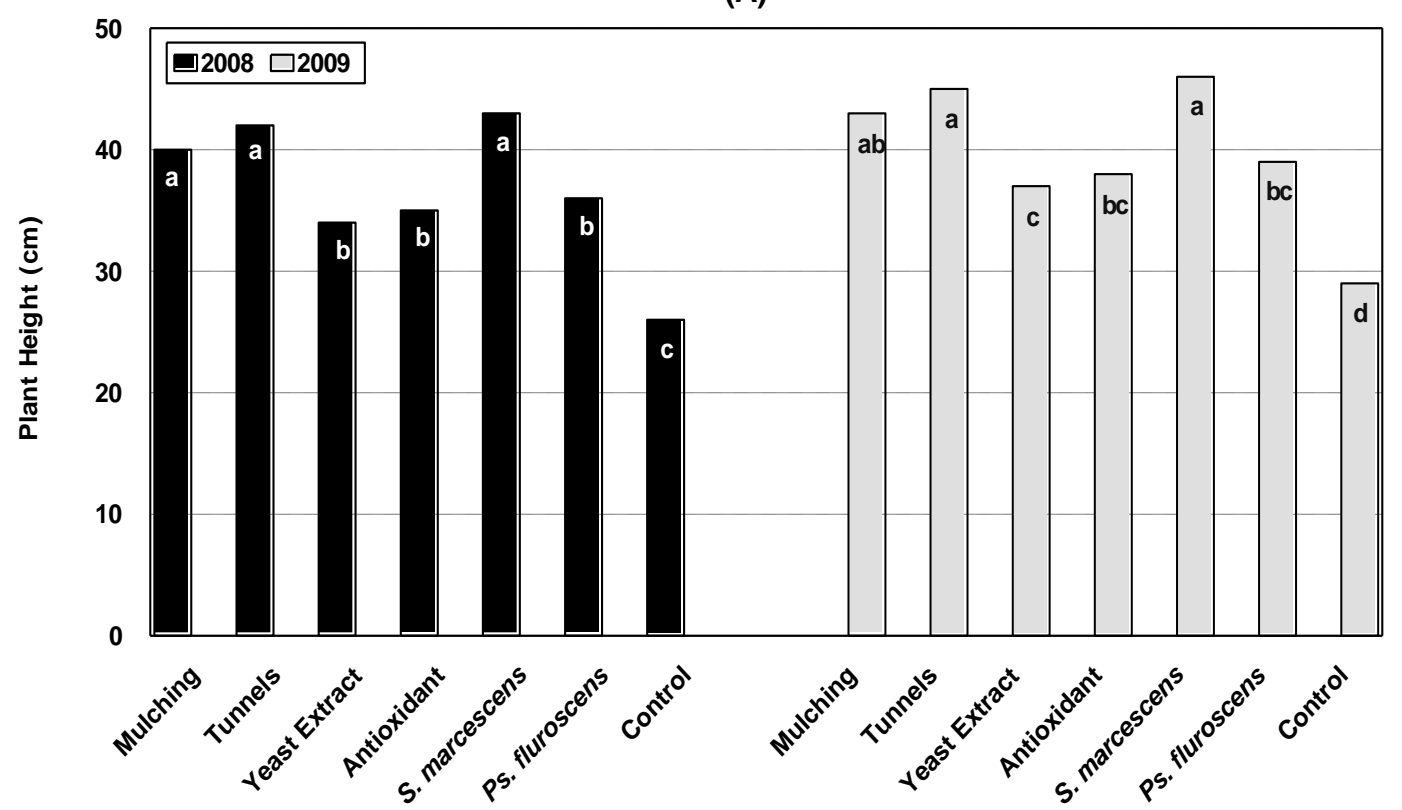

Figure 4. Effect of different treatments on plant height (A); leaves number (B); root length (C); false stem length (D); leaves $(E)$, stems $(F)$, roots $(G)$ fresh weights and leaves $(H)$, stems $(\mathrm{I})$, roots $(\mathrm{J})$ dry weights of strawberry plants grown in nematode naturally infested soil with Meloidogyne spp in 2008 and 2009 seasons 
Continued Fig. 4.

(B)

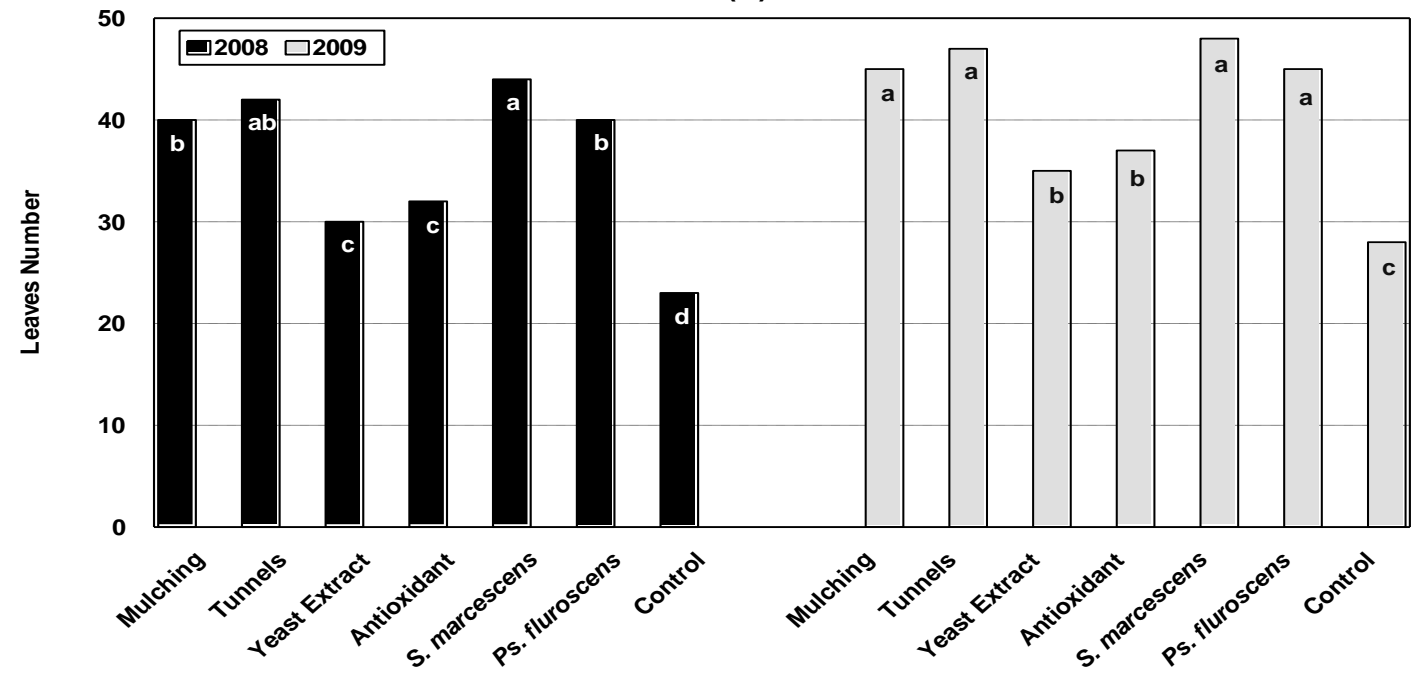

( C)

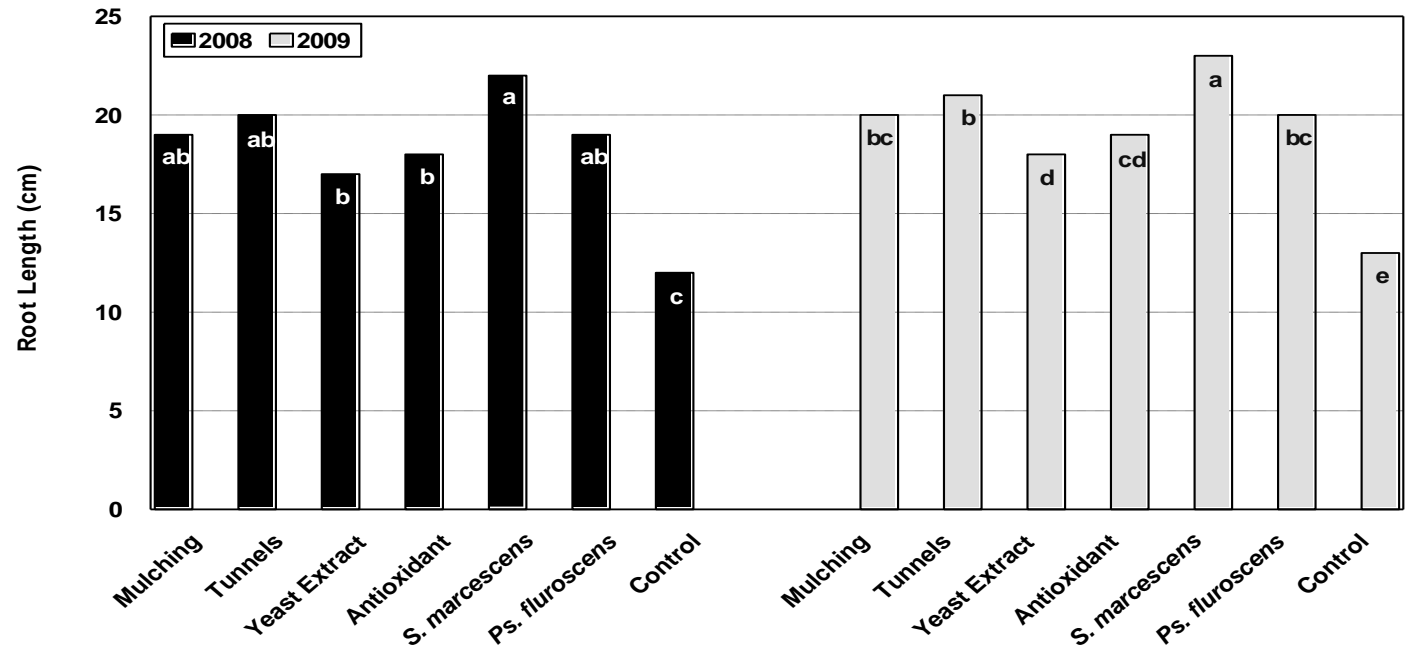

(D)

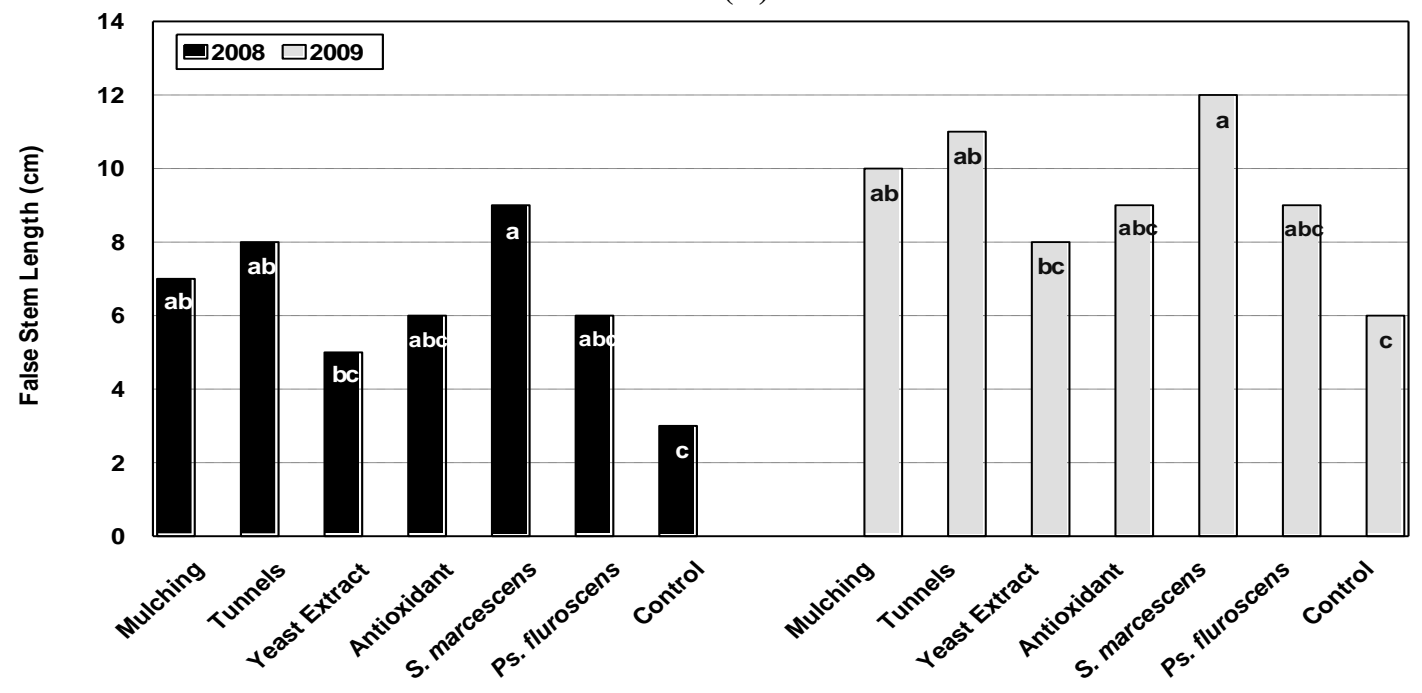

Arab Univ. J. Agric. Sci., 19(1), 2011 
Continued Fig. 4.

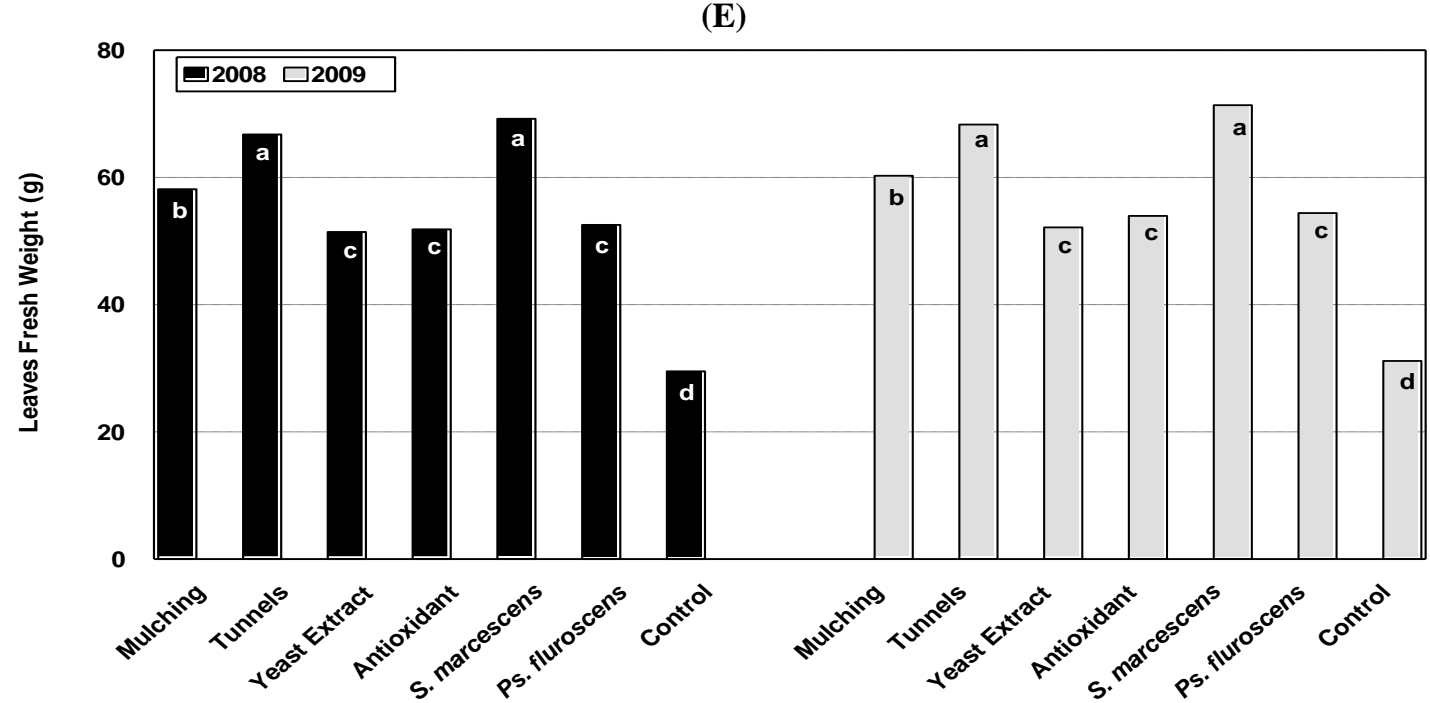

(F)

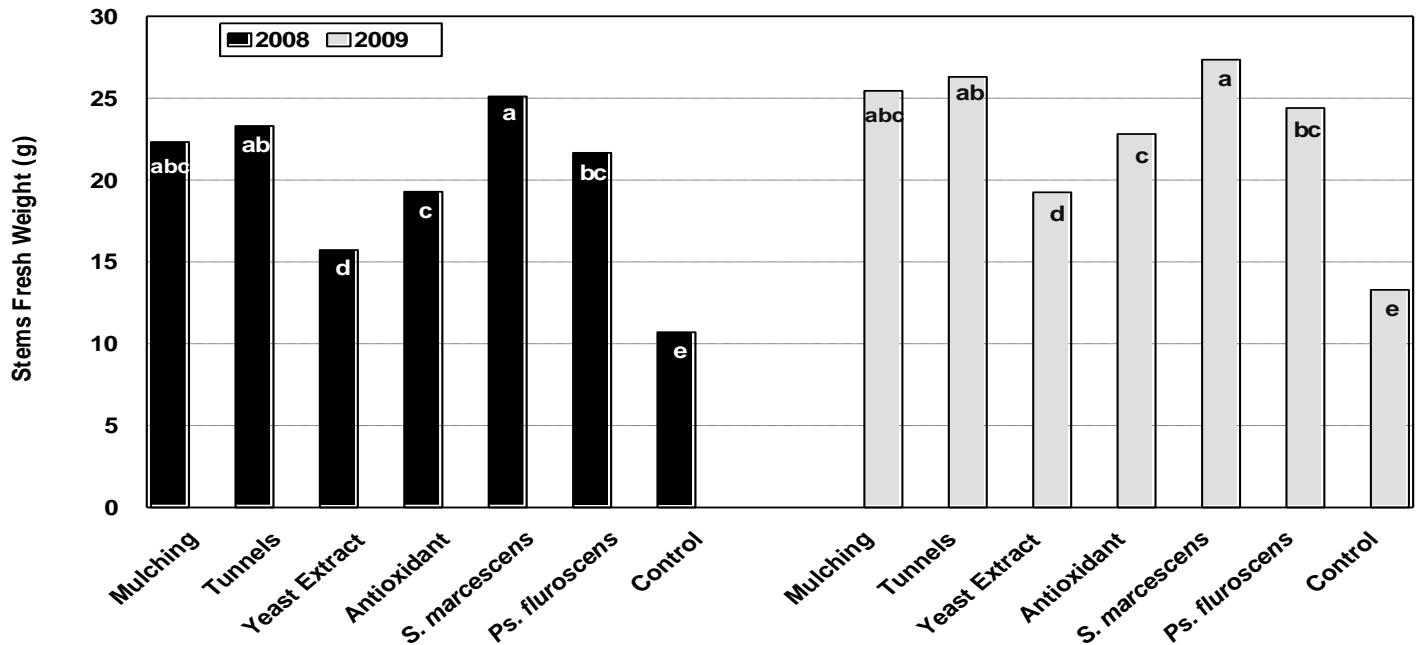

(G)

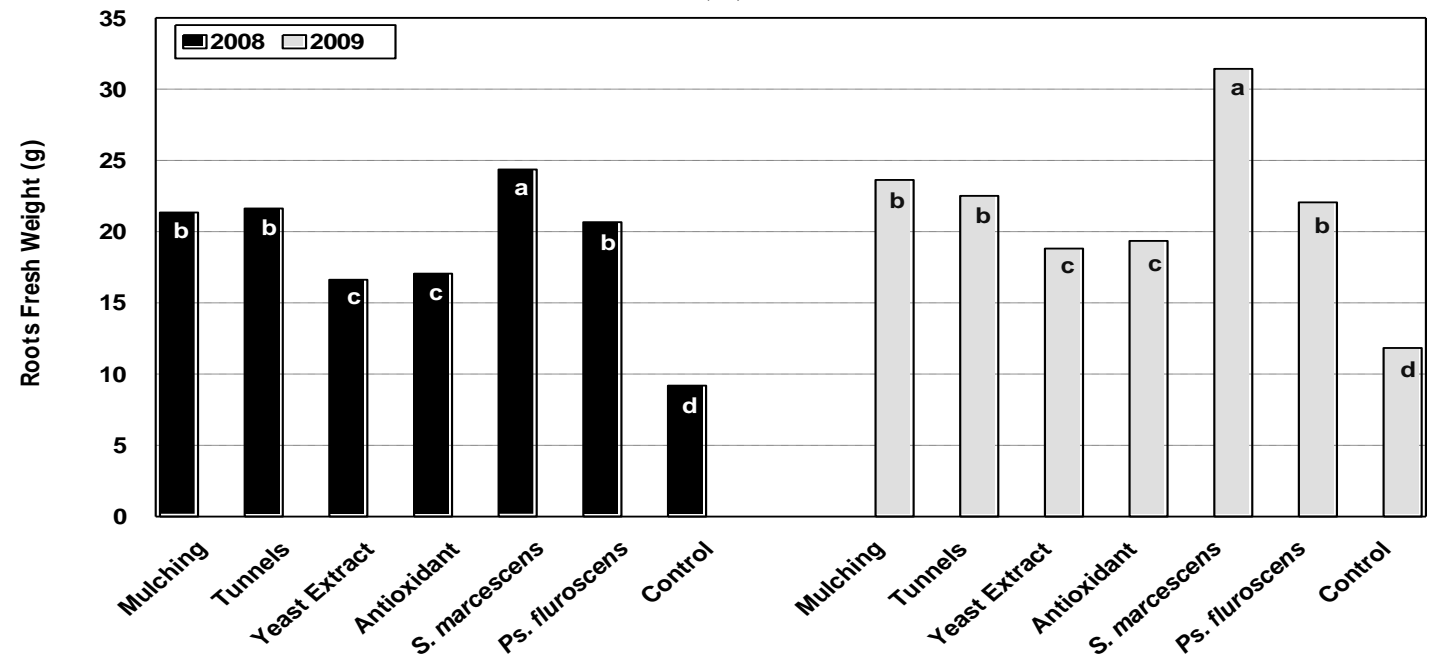

Arab Univ. J. Agric. Sci., 19(1), 2011 
Continued Fig. 4.

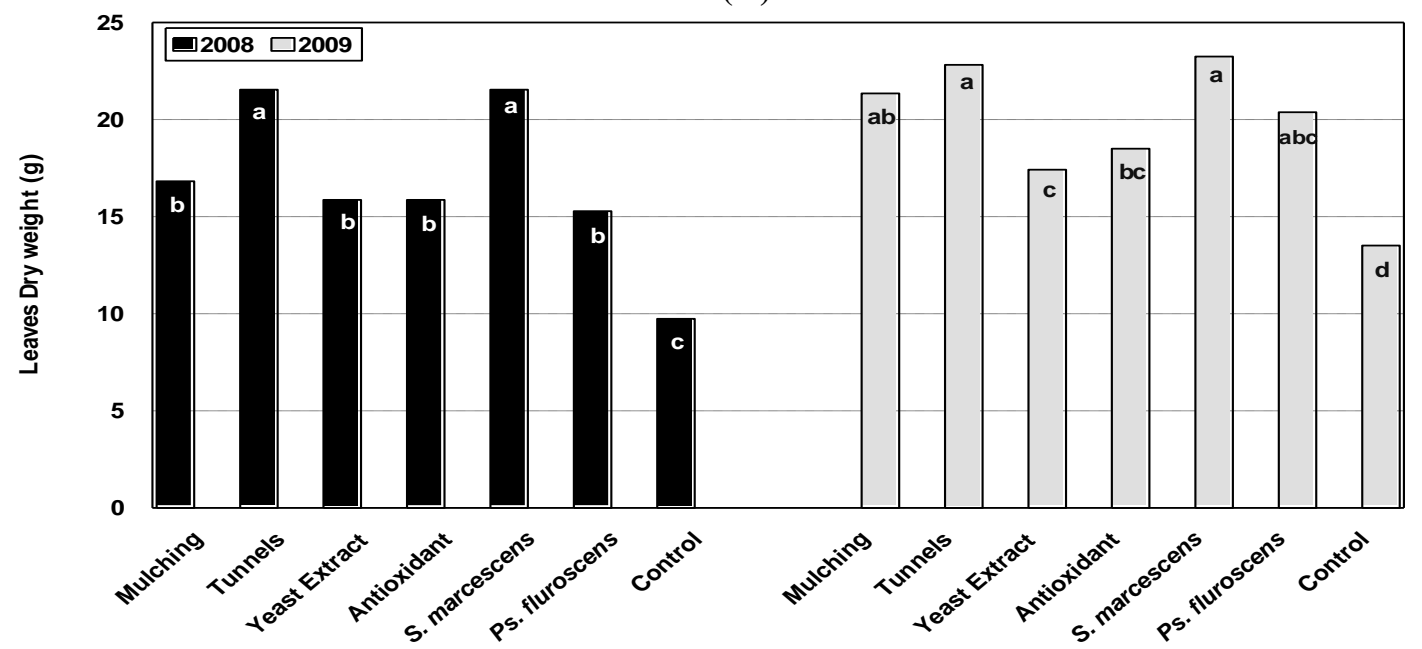

(I)

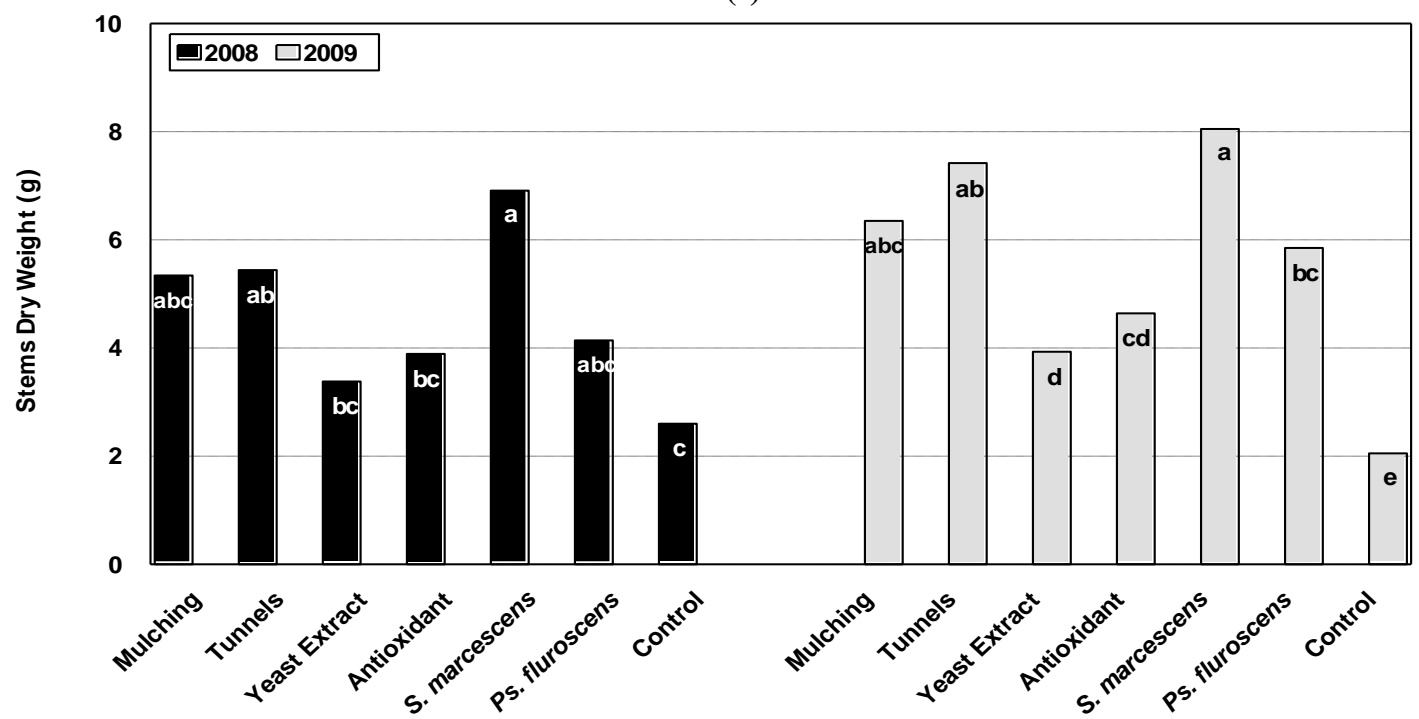

(J)

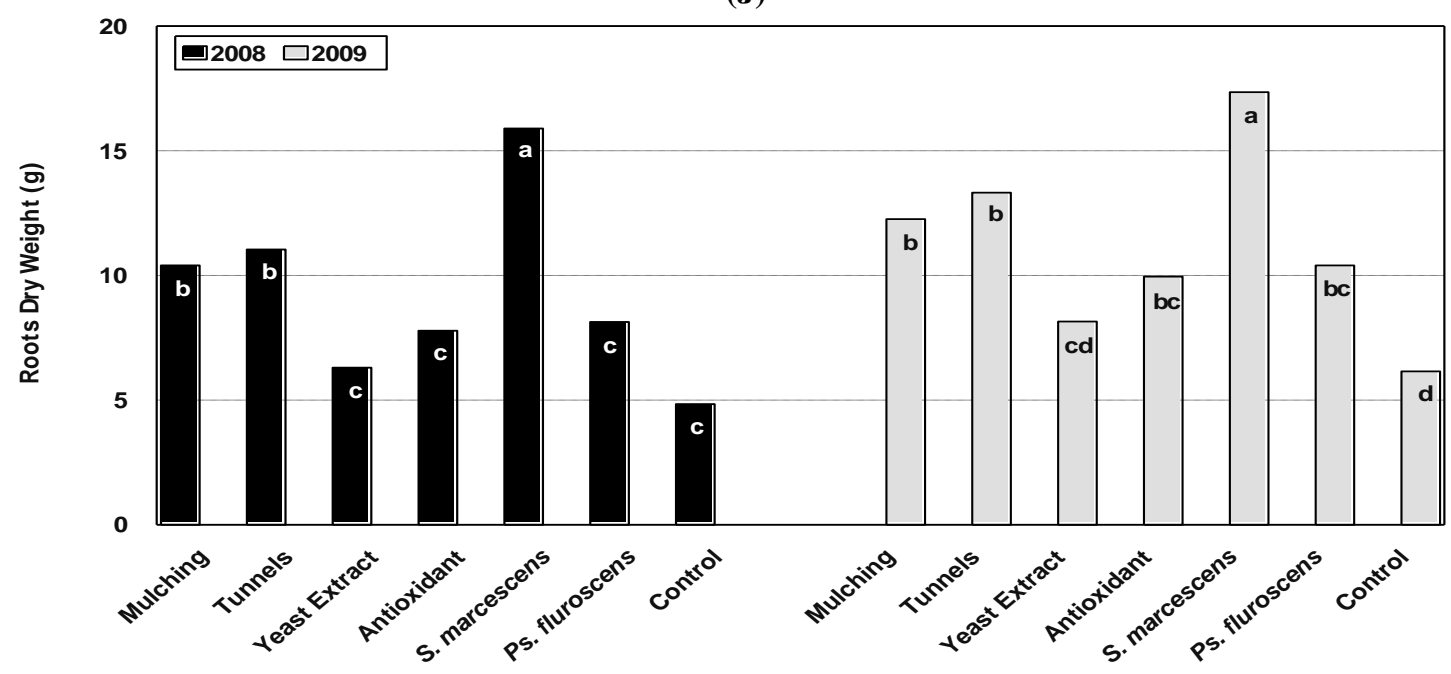

Arab Univ. J. Agric. Sci., 19(1), 2011 


\section{3- Fruit Chemical Constituents}

\section{a) Total Soluble Solids (T.S.S)}

Comparing to the control with the other tested treatments, antioxidants, natural yeast extract and $S$. marcescens approved to be more superior in increasing the total soluble solids in strawberry fruits significantly at all tested pickings as illustrated in Fig. (5). The other tested treatments showed no significant effect on T.S.S when compared with the untreated control.

\section{b) Ascorbic Acid (Vitamin C concentration)}

Data illustrated in Fig. (6) found that the significant value of Vitamin C (V.C) was obtained in treated plants with all tested treatments when compared with untreated plants. Moreover, the highest significant V.C value recorded in plants received antioxidant followed by natural yeast extract. These results being true in fruits of all tested pickings.

\section{c) Peroxidase and Phenoloxidase Enzymes Activity}

It was noticed that, all the tested treatments enhanced significantly the activity of both peroxidase and phenoloxidase enzymes when compared with the untreated plants as illustrated in Fig. (7, A\&B). However, results revealed that treating the plants with antioxidants was the best one in enhancing the activity of peroxidase enzyme followed by the natural yeast extract, whereas tunnels treatment the lowest effective one as illustrated in Fig. $(7, \mathbf{A})$.

Results in Fig. (7, B) recorded that, all tested treatments significantly enhanced the activity of phenoloxidase enzyme when compared with control. Generally the highest significant activity of phenoloxidase enzyme was observed in strawberry fruits due to antioxidant application, followed by the yeast extract treatment when they compared with the untreated control.

\section{4- Early and Total Yield}

All applied treatments seemed to affect, in a positive manner, the strawberry early and total yield either as $\mathrm{g} / \mathrm{plant}$ or as a ton/feddan as shown in Figure (8, A, B, C\&D). The highest records in strawberry yield in both seasons achieved, with applying both rhizobacteria $S$. marcescens and $P$. fluorescens, in addition to mulching and tunnels as illustrated in Fig. (8, A,B,C\&D).
It is evident from data shown in Fig. (8, A,B,C\&D) that untreated plants (naturally infested control) achieved, in general the lowest significant record in both early and total yield g/plant and ton/fed. On the other hand, S. marcescens showed the highest significant record. $P$. fluorescens, mulching and tunnels came at the $2^{\text {nd }}, 3^{\text {rd }}$ and $4^{\text {th }}$ rank, respectively. Yeast extract and antioxidant showed also somewhat superiority in this concern.

\section{DISCUSSION}

Results revealed that, mulching, $S$. marcescens, $P$. fluorescens and tunnels were effective treatments in reducing all related nematode parameters compared with the untreated control.

Black Mulching was common to encourage the plant growth by keeping the soil warmer, as the black mulch absorbs sunlight and allow the sun's radiant energy to be trapped in the soil, heating the upper levels and increasing the soil temperature to levels that kill many disease causing organisms (pathogens), nematodes and weed seeds and seedlings. Mulching changes also the physical and chemical features of soil that improve the growth and development of plants. It speeds up the breakdown of organic material in the soil, resulting in the release of soluble nutrients such as nitrogen $\left(\mathrm{No}_{3}, \mathrm{NH}_{4}^{+}\right)$. Calcium $\left(\mathrm{Ca}^{++}\right)$, magnesium $\left(\mathrm{Mg}^{++}\right)$, potassium $\left(\mathrm{K}^{+}\right)$and fulvic acid making them more available to plants (@).

Rhizobacteria, it is generally accepted that the effective microorganisms as a biocontrol agents and as plant-growth promoters should have a good rhizosphere competence i.e. an efficient ability to colonize roots (Weller, 1988) and play a major role in the biological equilibrium among microorganisms in the rhizosphere by their interaction with various plant pathogens. The rhizobacteria exhibit diverse modes of action that include parasitizing, producing toxins, antibiotics or enzymes interfering with nematode-plant-host recognition, competing for nutrients, inducing systemic resistance of plants and promoting plant health as well as act synergistically on nematodes through the direct suppression of nematodes and facilitating the rhizosphere colonization and activity of microbial antagonists (Tian et al 2007, a\&b).

Rhizobacteria mediated induced systemic resistance (ISR) in plants which has been shown to be active against nematode pests as reported by Van Loon et al (1998) and Ramamoorthy et al (2001). Plant growth promoting rhizobacteria can bring about ISR by fortifying the physical and mechanical strength of the cell wall by means of 


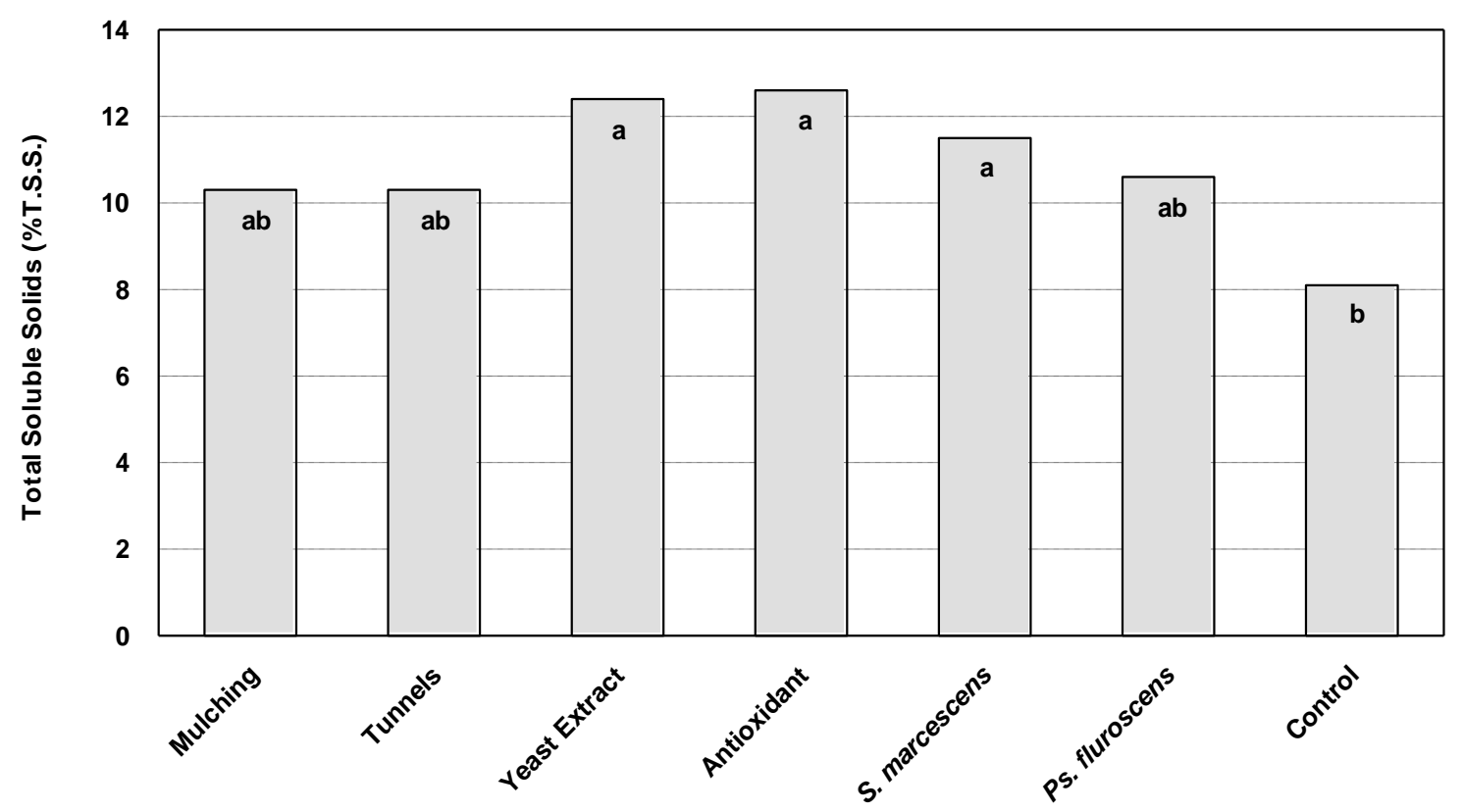

Figure 5. Total soluble solids in strawberry fruits grown in nematode naturally infested soil with Meloidogyne spp as affected by different treatments application in the second season

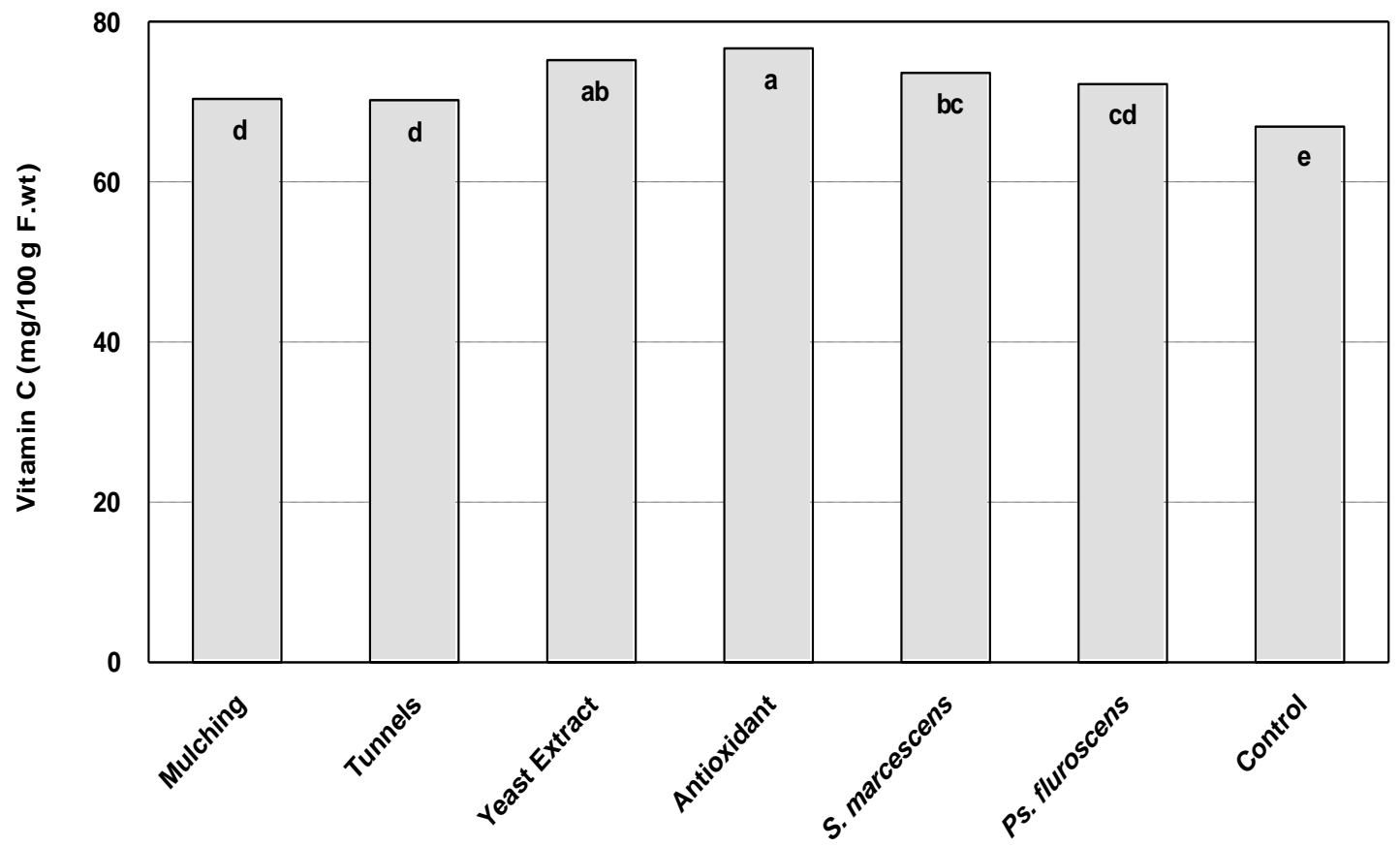

Figure 6. Vitamin C content in strawberry fruits grown in nematode naturally infested soil with Meloidogyne spp as affected by different treatments application in the second season. 
(A)

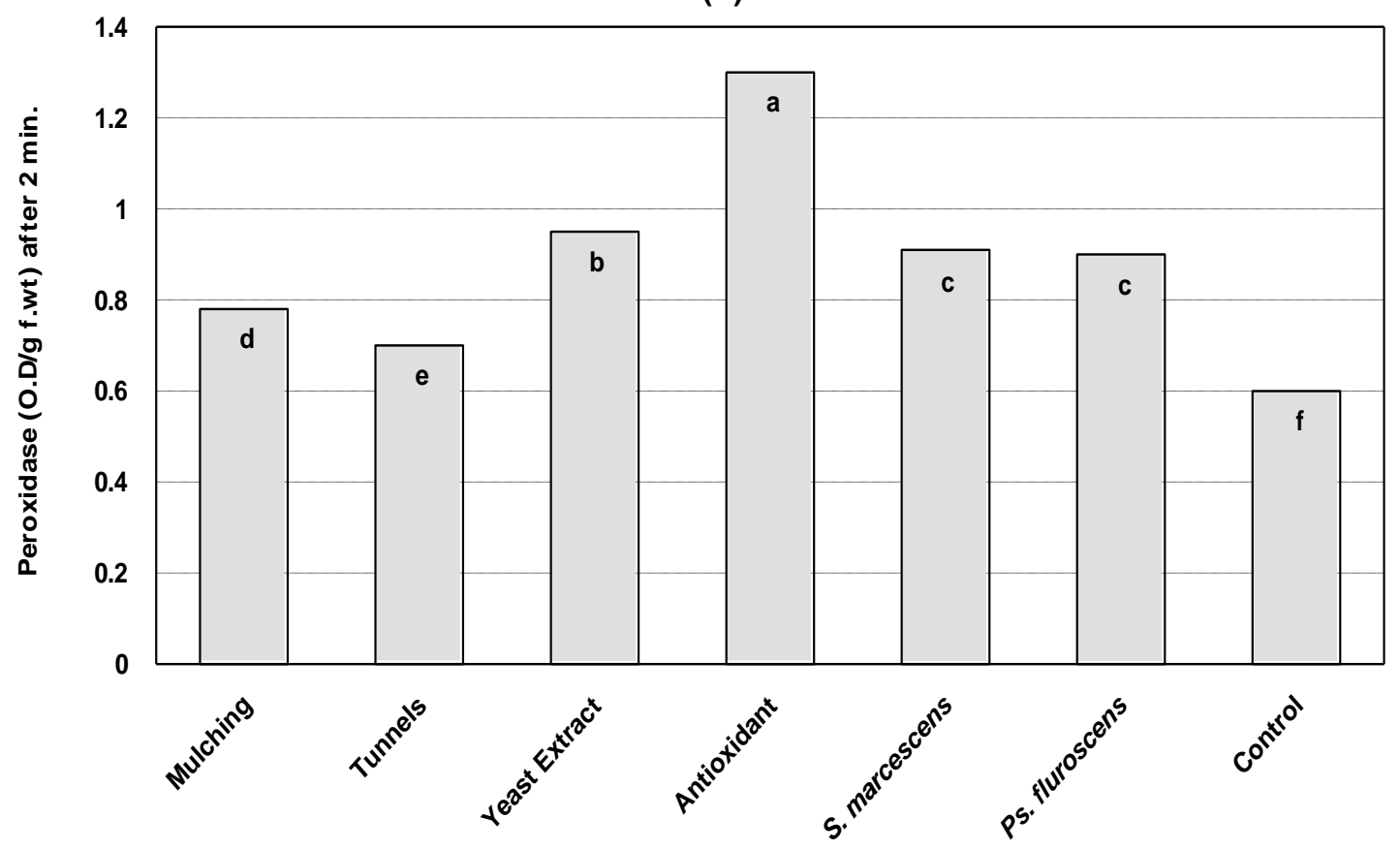

(B)

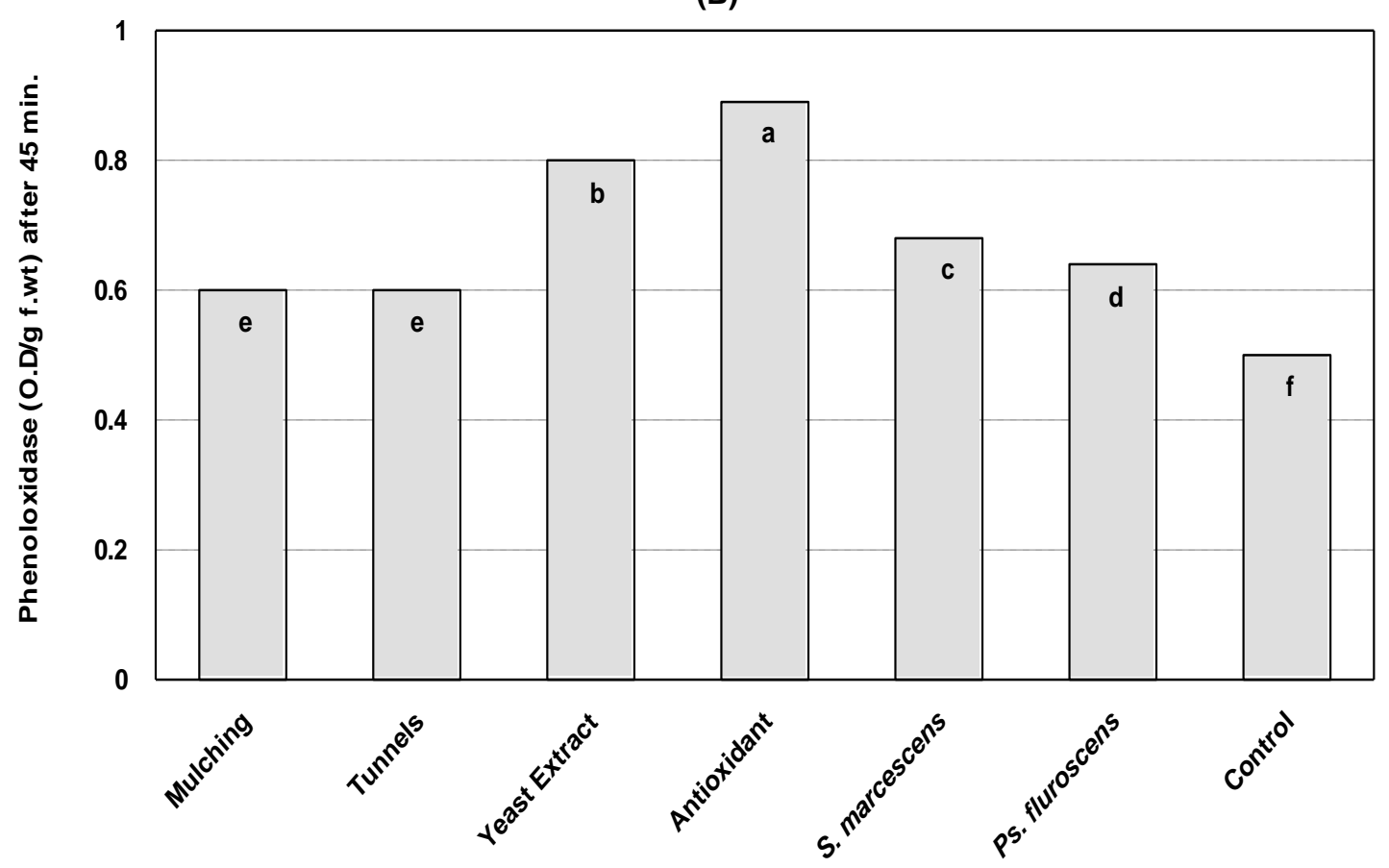

Figure 7, A\&B: Effect of different treatments on peroxidase (A) and phenoloxidase (B) enzymes activity in strawberry plants grown in naturally infested soil with Meloidogyne spp. in the second season. 
(A)

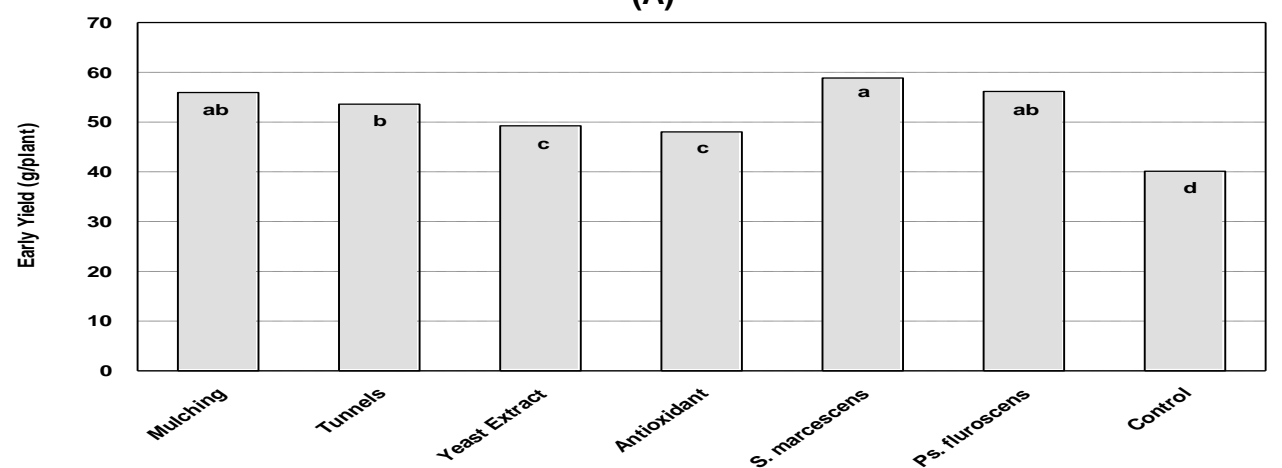

(B)

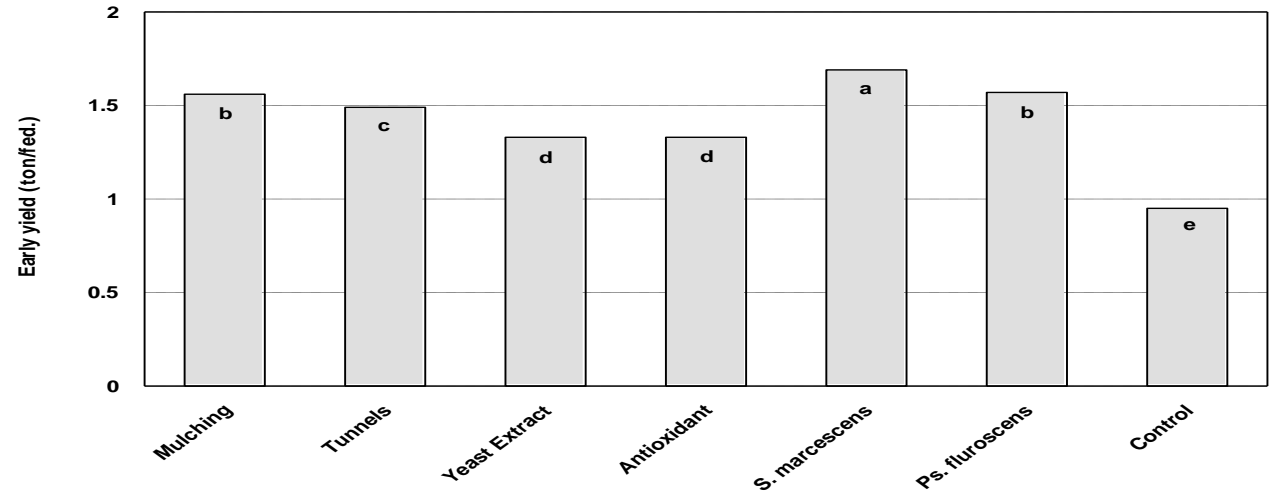

(C)

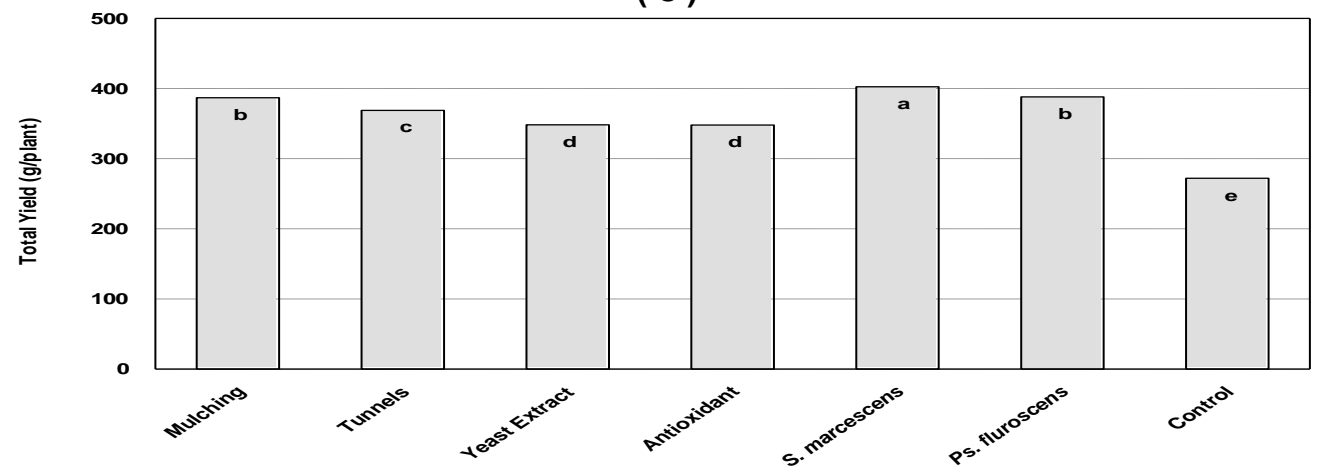

(D)

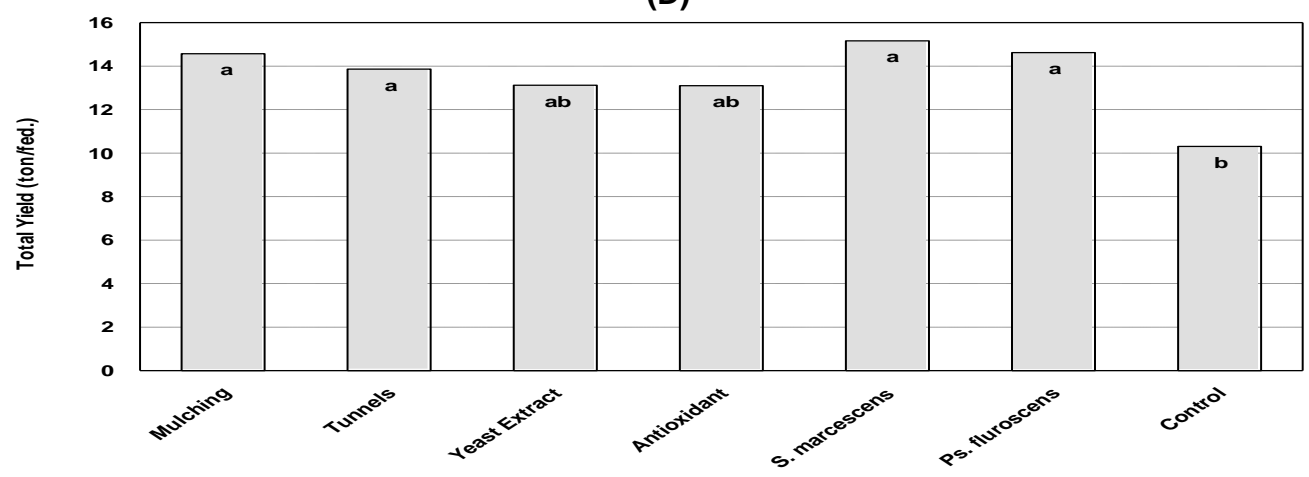

Figure 8. Effect of different treatments on early and total yield $\mathrm{g} / \mathrm{plant}$ and ton/feddan (A,B,C\&D) respectively of strawberry plants grown in naturally infested soil with Meloidogyne spp. in the second season 
cell-wall thickening, deposition of newly formed callose and accumulation of phenolic compounds. They also change the physiological and biochemical ability of the host to promote the synthesis of defense chemicals against the challenge pathogen e.g. by the accumulation of the pathogenesisrelated proteins, increased chitinase and peroxidase activity and other secondary metabolites as reported by Siddiqui and Mahmood (1999) and Ramamoorthy et al (2001). The mechanism involved in resistance development seems to be directly related to nematode recognition and penetration of the root (Reitz et al 2000; 2001 and Mahdy et al 2001).

S. marcescens is considered chitinolytic bacterium and has already been shown to effectively control plant pathogens (Sneh, 1981). Some strains of $S$. marcescens produced Salicylic acid (SA) which play an important role for induction of systemic resistance and consequently in the reduction of disease severity as reported by Press et al (1997).

Pseudomonas spp. influence the intimate relationship between the plant-parasitic nematodes and their hosts through production of metabolites which reduce egg hatching and through attraction and degradation of specific root exudates that control nematode behavior as reported by Sikora and Hoffmann-Hergarten, (1993). One of this metabolites produced by Pseudomonas are 2,4diacetylphloroglucinol (2,4-DAPG), has received particular attention because of its production by a wide range of Pseudomonades used for the biological control of root diseases. 2,4-DAPG is a phenolic compound with broadspectrum antifungal, antibacterial, antihelmenthic, nematicidal and phytotoxic activity, Siddiqui and Shaukat (2003) revealed that treating the plants with Ps. fluorescens culture filtrate reduced the ability of $M$. javanica eggs to hatch and induce mortality in juveniles.

Antioxidants treatments showed markedly increase in all chemical constituents, peroxidase and phenoloxidase enzymes activities and total yield/feddan followed by yeast and $S$. marcescens. Antioxidants were found to exert positive effect and overcome the harmful effect of some environmental stress on plant growth (Sally and Mervat, 2010; Cakmak and Marscher, 1992). Antioxidants protect chloroplast and electron transport system. They also stimulate respiration activity, cell division and many enzymes activities (Oertli, 1987). Antioxidants increase the tolerance to various stresses as well as improving the growth traits surely reflected on stimulating the nutritional status of the plants. These advantages of the antioxidants may be attributed to enhancing the uptake of the nutrients by the plants and consequently increase the total yield of plants as reported by Ahmed et al (2002).

Yeast extract as a natural substance contain many growth materials and essential elements needed for vegetative growth of different plants.Yeast extracts are also rich in phytohormones, vitamins, amino acids and energy (EIDesouky et al 1998). So for this reasons, it may enhance the plant growth, yield and chemical constituents i.e. T.S.S., V.C. as well as oxidative enzymes activity i.e. peroxidase and phenoloxidase. Furthermore, yeast via its cytokinins content (Skoog and Miller, 1957) might be play a role in orientation and translocation of metabolites from leaves into the reproductive organs (Savenkova, 1984). Also it might be play a role in the synthesis of protein and nucleic acids and minimized their degradation (Legocka, 1987). All of these occurrences and attributes might lead to the improvement of strawberry yield.

\section{REFERENCES}

Ahmed, F.F.; O.H. Darwish; A.A. Cobara and A.H. Ali (2002). Physiological studies on the effect of ascorbic and citric acids in combined with some micronutrients on flame seedless grabevine. Minia Agric. Res. and Develop., 22(1): 105-114.

A.O.A.C. (1990). Official Methods of Analysis of the association of official analytical chemists. $15^{\text {th }}$ Ed. Vol. I.: pp. 47-57.

Broesh, S. (1954). Colorimetric assay of phenoloxidase. Bull. Soc. Chem. Biol., 36: 711-713.

Cakmak, T. and H. Marschner (1992). Magnesium deficiency and high intensity enhance activities of superoxide dismutase, ascorbite peroxidase and glutathione reductase in bean leaves. Plant Physiol., 98: 1222-1227.

Daykin, M.E. and R.S. Hussey (1985). Staining and Histopathological Techniques in Nematology. In: Barker, K. R.; C. C. Carter Applied and Environmental Microbiology 63: 13571361.; J. N. Sasser (eds.): An Advanced Treatise in Meloidogyne, Vol. II Methodology, pp. 39-48. North Carolina State Univ. Graphics, Raleigh.

EI-Desouky, S.A.; A.L. Wanas and Z.M. Khedr (1998). Utilization of some natural plant extracts of garlic and yeast as seed-soaked materials to squash (Cucurbita pepo L.). 1. Effect on growth, sex expression and fruit yield and quality. Annals of Agricultural Science Moshtohor, 36(2): 839-854.

Fehrman, H. and A.E. Dimond (1967). Peroxidase activity and Phytophthora resistance in 
different organs of the potato. Plant Pathology, 57: 69-72.

Legocka, J. (1987). Kinetin-induced changes in the population of translatable messenger RNA lacking a polyadenylated segment in cucumber cotyledons. Acta Physiol. Plant., 9(1):3338.

Magdy El-Sayed Mahdy (2002). Biological Control of Plant Parasitic Nematodes with Antagonistic Bacteria on Different Host Plants. pp. 1-171. Ph.D Thesis, Institute of Plant Pathology, Bonn University, Germany.

Mahdy, M.; J. Hallmann and R.A. Sikora (2001). Influence of plant species on the biological control activity of the antagonistic rhizobacterium Rhizobium etli strain G12 toward the rootknot nematode Meloidogyne incognita. Meded Rijksuniv Gent Fak Landbouwkd Toegep Biol Wet 66: 655-662.

Netscher, C. and R.A. Sikora (1990). Nematode parasites on vegetables. In: M. Luc; J. Bridge and R. A. Sikora (eds.). Plant Parasitic Nematode in Subtropical and Tropical Agriculture. pp. 237-284 CAB International, Wallingford, UK.

Oertli, J.J. (1987). Exogenous application of vitamins as regulators for growth and development of plant. Zeitschrift fuer Pflanzenernharung und Bodenkuende 150: 375391.

Press, C.M.; M. Wilson; S. Tuzun and J.W. Kloepper (1997). Salicylic acid produced by Serratia marcescens $90-166$ is not the primary determinant of induced systemic resistance in cucumber or tobacco. Molecular PlantMicrobe Interaction 10: 761-768.

Ramamoorthy, V.; R. Viswanathan; T. Raguchander; V. Prakasam and R. Samiyappan (2001). Induction by systemic resistance by plant growth promoting rhizobacteria in crop plants against pests and disease. Crop Protection 20: 1-11.

Reitz, M.; S. Hoffmann-Hergarten; J. Hallmann and R.A. Sikora (2001). Induction of systemic Resistance in Potato by Rhizobacterium Rhizobium etli strain G12 is not associated with accumulation of pathogenesisrelated proteins and enhanced lignin biosynthesis. Zeitschrift Pflanzenkrankheiten und Pflanzenschutz 108: 11-20.

Reitz, M.; K. Rudolph; L. Schroeder; S. Hoffmann-Hergarten; J. Hallmann and R.A. Sikora (2000). Lipopolysaccharides of Rhizobium etli strain G12 act in potato roots as an inducing agent of systemic resistance to infection by the cyst nematode Globodera pallida.
Applied and Environmental Microbiology 66: 3515-3518.

Sally A. Midan and Mervat E. Sorial (2010). Protection of tomato plants against cold stress by using antioxidants, chilling hardening and jasmonic acid. Minufiya J. Agricultural Research 35(2): 663-685.

Savenkova, L.M. (1984). A possibility of regulating the seed of lupin with physiologically active substances. Referativity Zhumal, 55(6): 426 (C.F. Plant Growth Regulator Abstract, 12: 424).

Schneider, S.M.; E.N. Rosskopf; J.G. Leesch; D.O. Chellemi; C.T. Bull and M. Mazzola (2003). Research on alternatives to methyl bromide: pre-plant and post-harvest. Pest Management Science 59: 814-826.

Siddiqui, I.A. and S.S. Shaukat (2003). Suppression of root-knot disease by Pseudomonas fluorescens $\mathrm{CHAO}$ in tomato: importance of bacterial secondary metabolite 2,4diacetylphloroglucinol. Soil Biology and Biochemistry 35: 1615-1623.

Siddiqui, Z.A. and I. Mahmood (1999). Role of bacteria in the management of plant parasitic nematodes: a review. Bioresource and Technology 69: 167-179.

Sikora, R.A. and S. Hoffmann-Hergarten (1993). Biological control of plant parasitic nematodes with plant-health promoting rhizobacteria. Biologically Based Technology (Lumsden P.D. \& Vaugh J.L. eds), pp. 166-172. ACS Symposium Series, USA.

Skoog, E. and C.O. Miller (1957). Biological Action of Growth Substances. Cambridge Univ., Press, Cambridge.

Sneh, B. (1981). Use of rhizosphere chitinolytic bacteria for biological control of Fusarium oxysporum f. sp. dianthi in carnation. Phytopathologische Zeitschrift 100: 251-256.

Tian, B.; J.K. Yang; L.H. Lian; C.Y. Wang and K.Q. Zhang $(2007, a)$. Role of neutral protease from Brevibacillus laterosporus in pathogenesis of nematode. Applied Microbiology and Biotechnology 74: 372-380.

Tian, B.; J.K. Yang and K.Q. Zhang (2007, b). Bacteria used in the biological control of plant parasitic nematodes: populations, mechanisms of action and future prospects. FEMS Microbiology and Ecology 61: 197-213.

Van Loon, I.C.; P. Barker and C.M. Pierterse (1998). Systemic resistance induced by rhizosphere bacteria. Annual Review of Phytopathology 36: 453-483.

Weller, D.M. (1988). Biological control of soil borne plant pathogens in the rhizosphere with bacte- 
ria. Annual Review of Phytopathology 26:

379-407.

Arab Univ. J. Agric. Sci., 19(1), 2011 